\title{
Yield, quality and water use efficiency of processing tomatoes produced under different irrigation regimes in Mediterranean environment
}

\author{
Stella Lovelli, Giovanna Potenza, Donato Castronuovo, Michele Perniola, Vincenzo Candido \\ School of Agricultural, Forestry, Food and Environmental Sciences, University of Basilicata, Potenza, Italy
}

\begin{abstract}
Marketable yield is the main objective in tomato production, but fair values for quality parameters are also becoming very important. A research project was undertaken for two years to assess the impact of water-saving techniques on yield, fruit quality and water use efficiency (WUE) of processing tomato (cv. Pullrex) in the Mediterranean environment. Additionally, to better understand how irrigation may affect tomato traits, different statistical techniques were applied to the results. Total yield was reduced by $37 \%$ on average in both years when half of the crop evapotranspiration (ET) was restored, and maximum marketable tomato yield was obtained under irrigation when $100 \%$ of the crop ET was restored. Irrigation cut at tomato veraison (irrigation cutback treatment) did not affect the yield, enhanced fruit quality and maximised WUE, thus contributing to water saving. Through the application of irrigation cutback toward the end of the tomato cycle, there is a possibility to improve tomato quality and, at the same time, save irrigation water. Principal component analysis confirmed that the cutback of irrigation was well correlated with tomato quality.
\end{abstract}

\section{Introduction}

Climatic models predict increased drought in the $21^{\text {st }}$ century over most of southern Europe. Severe drought conditions can pro-

Correspondence: Giovanna Potenza, School of Agricultural, Forest, Food and Environmental Sciences, University of Basilicata, via dell'Ateneo Lucano 10, 85100 Potenza, Italy.

Tel. +39.0971.205384 - Fax: +39.0971.205378.

E-mail: giovanna.potenza@unibas.it

Key words: Cut-off irrigation; Lycopersicon esculentum Mill.; Soluble solids; Water stress; PC analysis.

Received for publication: 17 May 2016.

Revision received: 19 August 2016.

Accepted for publication: 7 September 2016.

CCopyright S. Lovelli et al., 2017

Licensee PAGEPress, Italy

Italian Journal of Agronomy 2017; 12:795

doi:10.4081/ija.2016.795

This article is distributed under the terms of the Creative Commons Attribution Noncommercial License (by-nc 4.0) which permits any noncommercial use, distribution, and reproduction in any medium, provided the original author(s) and source are credited. foundly impact agriculture, water resources, and ecosystems (Lovelli et al., 2010, 2012).

In agriculture, increasing water productivity is necessary for three important reasons: first, to achieve a sustainable use of this environmental resource; second, to reach food security for the increasing global population under climate change; and finally, to increase profitability for farmers who use water, which is also required by other sectors for other uses, as a production factor.

We have an opportunity to enhance water productivity in agriculture by utilising deficit irrigation strategies. The amount of water used under deficit irrigation is reduced in comparison to that normally needed by plants. Actually, it is possible to apply water below the amount required for evapotranspiration (ET) to save water for alternative uses (Fereres and Soriano, 2007; Geerts and Raes, 2009; Giuliani et al., 2016). Deficit irrigation strategies for tomatoes have been studied with contrasting results (Sanders et al., 1989; Obreza et al., 1996; Pulupol et al., 1996; Candido et al., 2000, 2015; Kirda et al., 2004; Patanè and Cosentino, 2010; Zheng et al., 2013; Colella et al., 2014; Buttaro et al., 2015; Cantore et al., 2016) and in many cases, the available information refers to greenhouse tomatoes, with less information available on open-field tomatoes grown under deficit irrigation (Patanè and Cosentino, 2010). The impact of deficit irrigation on tomato quality is still being debated. Currently, food quality as a means of enhancing the nutritional value of a diet is an important research field because two billion people around the world have micronutrient deficiencies (Garnett et al., 2013). According to some authors, more effort should be directed towards an increase of food quality (Garnett et al., 2013). Marketable yield is the main objective in tomato production, but fair values for quality parameters are also becoming very important; although the yield remains crucial for food security in the future, attention should be paid to improving tomato quality, from standard quality characteristics to functional, environmental and traceability ones.

The integrated use of multivariate analysis, such as principal component analysis (PCA) and univariate analysis is a suitable tool for studying the complex interactions between agronomic traits and fruit chemical composition on tomato. If univariate analysis (ANOVA) shows significant differences between treatments when investigated parameters are considered individually, PCA allows obtaining a new set of orthogonal factors that explain the shape of correlations and better captures most of the variance in the initial data set (Stellacci et al., 2012).

A two-year research project was undertaken to assess the impact of deficit irrigation on the water-use efficiency, yield and quality of processing tomatoes produced in Mediterranean environment. Different statistical techniques were applied to the results. In particular, an integrated approach based on the combined use of univariate analysis (ANOVA) and PCA was adopted. 


\section{Materials and methods}

\section{Experimental site characteristics}

Field experiments were carried out in the years 2002 and 2003 in Basilicata Region (southern Italy), at Gaudiano di Lavello (Potenza province, $41^{\circ} 03^{\prime} \mathrm{N}$ e $15^{\circ} 42^{\prime} \mathrm{E}, 180 \mathrm{~m}$ asl), on processing tomato (Lycopersicon esculentum Mill., cv. Pullrex) grown in a sandy-silt soil (sand: $49.7 \%$, silt: $28.3 \%$ and clay: $21.9 \%$ ), with the following characteristics: average depth, $70 \mathrm{~cm}$; $\mathrm{pH}, 7.10$; organic matter, $1.58 \%$; total nitrogen, $0.97 \%$; $\mathrm{CaCO}_{3}, 1.06 \%$; $\mathrm{P}_{2} \mathrm{O}_{5}, 88.20$ ppm; $\mathrm{K}_{2} \mathrm{O}, 210 \mathrm{ppm}$; volumetric water content, $0.38 \mathrm{~m}^{3} \mathrm{~m}^{-3}$ at field capacity $(-0.03 \mathrm{MPa})$ and $0.21 \mathrm{~m}^{3} \mathrm{~m}^{-3}$ at the wilting point $(-1.5$ $\mathrm{MPa}$ ); bulk density, $1.25 \mathrm{~kg} \mathrm{dm}^{-3}$. The climate of this site is subhumid, according to the De Martonne climatic classification (Cantore et al., 1987).

\section{Treatments and experimental design}

Six irrigation treatments were compared (Table 1): i) four constant irrigation schedule with restoration of 0 (T0, dry control, irrigated only at transplanting time), 50 (T1), 75 (T2) and 100\% (T3, fully irrigated control) of crop ET (ETc), over the whole crop cycle; ii) two variable irrigation schedule with a $100 \%$ restoration of the ETc during the first period of the crop cycle, followed by a 75 or $50 \%$ restoration of the ETc in the second part of the cycle, beginning with berry veraison (irrigation cutback, T4 and T5 treatments, respectively). Experimental treatments were arranged in the field according to a randomised complete blocks design with three replicates; each plot (experimental unit) had a surface of $15.4 \mathrm{~m}^{2}$ and consisted of three twin rows.

\section{Crop management}

Tomato seedlings were transplanted on May 17, 2002 and June 3,2003 , at the stage of $3^{\text {rd }}-4^{\text {th }}$ true leaf, at a distance of $40 \mathrm{~cm}$ apart in twin rows spaced $50 \mathrm{~cm}$ apart. A $170 \mathrm{~cm}$ distance separated each pair of rows, resulting in a plant density of 2.94 plants $\mathrm{m}^{-2}$.

Basic fertilisation was made with the addition of $72 \mathrm{~kg} \mathrm{ha}^{-1}$ of $\mathrm{N}$ and $184 \mathrm{~kg} \mathrm{ha}^{-1}$ of $\mathrm{P}_{2} \mathrm{O}_{5}$ before transplanting; while 110, 30 and $160 \mathrm{~kg} \mathrm{ha}^{-1}$ of $\mathrm{N}, \mathrm{P}_{2} \mathrm{O}_{5}$ and $\mathrm{K}_{2} \mathrm{O}$, respectively, were supplied through fertigation during the crop cycle

A micro-flow drip irrigation method was used with dripping wings and distributors giving $2 \mathrm{~L} \mathrm{~h}^{-1}$, spaced $20 \mathrm{~cm}$ apart and placed along the row. After an initial distribution of $200 \mathrm{~m}^{3} \mathrm{ha}^{-1}$ of water at transplant in all treatments, further irrigations were carried out following evapotranspiration criterion according to a simplified soil water balance $\left(\mathrm{ETc}=\mathrm{ET}_{0} \times \mathrm{K}_{\mathrm{C}}\right)$. Waterings were carried out when the cumulative ETc minus effective rain reached $40 \mathrm{~mm}$ starting from the last watering.

The ETc was measured with an atmometer (Et-Gage), and the crop coefficients $(\mathrm{Kc})$ used were those obtained in the Basilicata region from a similar environment (Tarantino and Onofri, 1991), with values of 0.35 from transplant to establishment, 0.55 up to the start blooming, 0.90 from blooming to fruit-set, 1.1 during fruit growth, and 0.95 from the beginning of fruit ripening to harvest. Weeds were controlled by chemical treatment with Treflan ( $\alpha, \alpha, \alpha$ trifluoro-2,6-dinitro-N,N-di propil-p-toluidine) before transplant and afterwards by tillage. Pests and diseases were controlled by specific agrochemicals for tomatoes when necessary, according to the production disciplinary of Basilicata Region. Harvest was performed manually on August 28, 2002, and September 25, 2003.

\section{Measurements performed \\ Yield, biomass and water use efficiency}

At harvest, tomato yields were detected by recording number and weight of total, marketable and waste fruits from 12 plants (sampling area of $4.08 \mathrm{~m}^{2}$ ) on the central twin row of each plot. The harvest index (HI) was calculated at harvesting as the ratio between dry fruit yield and total dry above ground biomass. Wateruse efficiency (WUE, $\mathrm{kg} \mathrm{m}^{-3}$ ) was calculated as the ratio between total above ground plant dry biomass and total water use (effective rainfall, irrigation water applied and soil moisture changes during the growing season).

\section{Fruit quality}

The following fruit quality parameters were assessed: dry matter (total solids, TS), soluble solids (TS), pH, titratable acidity and vitamin C. For dry matter content measurement, 5 fruits of a homogeneous tomato sample were dried in a conventional oven at $72^{\circ} \mathrm{C}$ until a constant weight was achieved. The $\mathrm{pH}$ was measured using a pH meter (Orion ${ }^{\circledR}$ SA720; Orion Research, Boston, MA, USA) equipped with a probe for solids (FC 200B; Hanna Instruments, Woonsocket, RI, USA). Titratable acidity was determined by titration with $\mathrm{NaOH} 0.1 \mathrm{~mol} \mathrm{~L}^{-1}$ to reach $\mathrm{pH} 8.1$, with the results being expressed in grams of anhydrous citric acid per $100 \mathrm{~g}$. The total

Table 1. Seasonal irrigation volumes and other irrigation parameters for each irrigation treatment, in the two cropping seasons.

\begin{tabular}{|c|c|c|c|c|c|}
\hline Irrigation treatments (\%) & Code & $\begin{array}{l}\text { Seasonal irrigation volume } \\
\qquad\left(\mathrm{m}^{3} \mathrm{ha}^{-1}\right)\end{array}$ & $\begin{array}{l}\text { Irrigation period } \\
\text { (d) }\end{array}$ & $\begin{array}{l}\text { Irrigations } \\
\text { (n) }\end{array}$ & $\begin{array}{l}\text { Irrigation turn } \\
\text { (d) }\end{array}$ \\
\hline \multicolumn{6}{|l|}{2002} \\
\hline 0 & T0 & 200 & 88 & 11 & 8.8 \\
\hline 50 & $\mathrm{~T} 1$ & 2155 & 88 & 11 & 8.8 \\
\hline 75 & $\mathrm{~T} 2$ & 3083 & 88 & 11 & 8.8 \\
\hline 100 & $\mathrm{~T} 3$ & 4010 & 88 & 11 & 8.8 \\
\hline $100-75$ & $\mathrm{~T} 4$ & 3551 & 88 & 11 & 8.8 \\
\hline $100-50$ & $\mathrm{~T} 5$ & 3092 & 88 & 11 & 8.8 \\
\hline \multicolumn{6}{|l|}{2003} \\
\hline 0 & T0 & 200 & 82 & 11 & 8.2 \\
\hline 50 & $\mathrm{~T} 1$ & 2323 & 82 & 11 & 8.2 \\
\hline 75 & $\mathrm{~T} 2$ & 3484 & 82 & 11 & 8.2 \\
\hline 100 & T3 & 4645 & 82 & 11 & 8.2 \\
\hline $100-75$ & $\mathrm{~T} 4$ & 4571 & 82 & 11 & 8.2 \\
\hline $100-50$ & $\mathrm{~T} 5$ & 4495 & 82 & 11 & 8.2 \\
\hline
\end{tabular}


soluble solid content was assessed using an Abbe refractometer (Carl Zeiss, Jena, Germany) calibrated against sucrose. For vitamin $\mathrm{C}$ extraction, $20 \mathrm{~g}$ of tomato sample for each plot was treated with liquid nitrogen to obtain a brittle sample that was then immediately homogenised for $45 \mathrm{~s}$ at 15,000 rpm using a Sterilmixer homogeniser (PBI International, Milan, Italy). To prevent vitamin degradation and to reduce dehydroascorbic acid to ascorbic acid prior to the homogenisation step, tomatoes were added with potassium metabisulfite $(0.2 \%$ by weight $)$ and kept in ice during homogenisation. The procedure was conducted under dim light, and all of the glassware was wrapped in aluminium foil to shield the product from light. Approximately $1 \mathrm{~g}$ of the sample was then transferred to a $10 \mathrm{~mL}$ amber volumetric flask and brought up to volume using a solution of $20 \mathrm{mM} \mathrm{NaH}_{2} \mathrm{PO}_{4}$ acidified to $\mathrm{pH} 2.1$ with $1 \mathrm{~N} \mathrm{HCl}$. The flask was then stirred five times for $5 \mathrm{~s}$, and the extract was filtered through a $0.2 \mu \mathrm{m}$ cellulose acetate filter (Alltech, Nicholasville, KY, USA) and stored in the dark at $-18^{\circ} \mathrm{C}$ in an amber vial in nitrogen until analysed. The vitamin $\mathrm{C}$ content was assessed by HPLC. The sample $(20 \mathrm{~mL})$ was injected onto a C18 Aqua column $(5 \mathrm{~mm}, 250 \times 4.6 \mathrm{~mm}$; Phenomenex, Torrance, CA, USA) with an Aqua C18 guard column $(4 \times 3 \mathrm{~mm} \mathrm{ID)}$. Separation of the vitamin $\mathrm{C}$ was obtained by isocratic elution with $\mathrm{NaH}_{2} \mathrm{PO}_{4}(20 \mathrm{mM})$ acidified at $\mathrm{pH} 2.14$ with $\mathrm{HCl} 1 \mathrm{~N}$ (flow-rate 1 $\mathrm{mL} \min ^{-1}$ ). Mobile phase acidification was needed to reduce the rapid oxidation of the L-ascorbic acid. Each sample was prepared and analysed in duplicate, and detection of the compound was carried out at $240 \mathrm{~nm}$ while the linearity of the UV detector for vita-

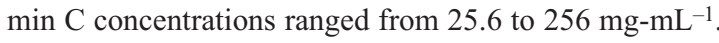

All chemicals were of suitable analytical grade and purchased from Carlo Erba (Milan, Italy). Ascorbic acid standards were obtained from Sigma (St. Louis, MO, USA).

\section{Climate parameters}

Weather data were collected during both tomato crops, from
May to September in 2002 and 2003. Air temperature was measured by $50 \mathrm{Y}$ probes (CS500-L mod; Campbell Scientific Inc., Logan, UT, USA), whereas an electronic tipping bucket rain gauge (TB4MM-L mod., $0.2 \mathrm{~mm}$ resolution, Campbell Scientific Inc.) was used for rain-fall measurement. All data were recorded by a CR 10× data-logger (Campbell Scientific Inc.). During the tomato crop cycles soil water status of each treatment was monitored by Bouyoucos resistive blocks, calibrated by means of a Richard chamber (Campbell and Gee, 1986) and placed at 20, 40 and $60 \mathrm{~cm}$ depth in the soil.

\section{Statistical analysis}

Bartlett's test was applied to establish homogeneity of variance, then data were subjected to analysis of variance (ANOVA), with the year and irrigation treatment being considered as sources of variation. The SNK test was also performed for comparison of means. Because the year effect was significant at $\mathrm{P}<0.05$ for all variables, with the exception of Harvest Index and fruit dry matter, ANOVA was performed separately per year, and the results are presented in Tables 2, 3 and 4. The percentage values were transformed into angular values according to the Bliss formula arcsin $\sqrt{ } \%$ before ANOVA was performed. Statistical analysis was perfomed using the Statistica V.10 (Statsoft Inc., Tulsa, OK, USA). Moreover, all data were subjected to a PCA with Ward's method (Wold et al., 1987; Jackson, 1991). A PCA model was calculated considering, for each irrigation treatment, the average values of replicates recorded for tomato quality parameters. A factor-loading table (Table 4) shows correlations between the principal components (PC1 and PC2) and the original parameters of quality that were measured. The graphical representation of the PCA results is a graph named a biplot, which is the superimposition of the loading plot on the corresponding score plot. In this way, it is also possible to view how the different irrigation regimes are distributed in the subspace of the principal components by means of the score plot.

Table 2. Total and marketable yield, discarded tomato, fruit per plant, dry matter of the yield, above ground biomass as dry matter and harvest index measured in the different irrigation treatments, for each year.

\begin{tabular}{|c|c|c|c|c|c|c|c|c|c|}
\hline $\begin{array}{l}\text { Irrigation } \\
\text { treatments }\end{array}$ & $\begin{array}{l}\text { Total yield } \\
\left(\mathrm{t} \mathrm{ha} \mathrm{a}^{-1} \mathrm{FW}\right)\end{array}$ & $\begin{array}{c}\text { Marketable } \\
\text { yield } \\
\left(\mathrm{t} \mathrm{ha^{-1 }} \text { FW) }\right.\end{array}$ & $\begin{array}{c}\text { Discarded tomato } \\
\left(\mathrm{t} \mathrm{ha}^{-1}\right)\end{array}$ & $\begin{array}{l}\text { Yield losses } \\
\text { (\%) }\end{array}$ & $\begin{array}{l}\text { Fruit } \\
\text { plant }^{-1} \\
\text { (n) }\end{array}$ & $\begin{array}{c}\text { Marketable } \\
\text { yield } \\
(\mathrm{t} \mathrm{ha-1} \mathrm{DW)}\end{array}$ & $\begin{array}{l}\text { Total yield } \\
\left(\mathrm{t} \mathrm{ha}^{-1} \mathrm{DW}\right)\end{array}$ & $\begin{array}{c}\text { Total } \\
\text { biomass } \\
\left(t \mathrm{ha}^{-1} \mathrm{DW}\right)\end{array}$ & HI \\
\hline \multicolumn{10}{|l|}{2002} \\
\hline T0 & $42.6^{\mathrm{d}}$ & $21.4^{c}$ & $21.2^{\mathrm{c}}$ & $57.1^{\mathrm{a}}$ & $18.9^{c}$ & $1.49^{b}$ & $2.98^{\mathrm{d}}$ & $7.46^{\mathrm{b}}$ & 0.40 \\
\hline $\mathrm{Tl}$ & $91.1^{\mathrm{c}}$ & $56.0^{\mathrm{b}}$ & $35.1^{\mathrm{b}}$ & $38.4^{\mathrm{b}}$ & $39.2^{\mathrm{b}}$ & $3.06^{\mathrm{a}}$ & $4.97^{c}$ & $9.14^{\mathrm{a}}$ & 0.34 \\
\hline $\mathrm{T} 2$ & $109.5^{b}$ & $70.5^{\mathrm{a}}$ & $39.0^{\mathrm{b}}$ & $35.6^{\mathrm{b}}$ & $40.5^{b}$ & $3.62^{\mathrm{a}}$ & $5.62^{b}$ & $9.67^{\mathrm{a}}$ & 0.37 \\
\hline T3 & $123.5^{\mathrm{a}}$ & $71.3^{\mathrm{a}}$ & $52.2^{\mathrm{a}}$ & $42.3^{b}$ & $51.6^{\mathrm{a}}$ & $3.73^{\mathrm{a}}$ & $6.46^{\mathrm{a}}$ & $10.15^{\mathrm{a}}$ & 0.37 \\
\hline T4 & $111.4^{b}$ & $66.5^{\mathrm{a}}$ & $45.0^{\mathrm{ab}}$ & $40.3^{b}$ & $37.0^{\mathrm{b}}$ & $3.57^{\mathrm{a}}$ & $5.98^{\mathrm{ab}}$ & $9.89^{\mathrm{a}}$ & 0.36 \\
\hline T5 & $110.1^{b}$ & $63.6^{\mathrm{a}}$ & $46.5^{\mathrm{ab}}$ & $42.2^{\mathrm{b}}$ & $36.2^{\mathrm{b}}$ & $3.59^{\mathrm{a}}$ & $6.20^{\mathrm{ab}}$ & $9.80^{\mathrm{a}}$ & 0.37 \\
\hline P & $* * *$ & $* * *$ & $* * *$ & $* *$ & $* * *$ & $* * *$ & $* * *$ & $* * *$ & ns \\
\hline \multicolumn{10}{|l|}{2003} \\
\hline T0 & $14.5^{\mathrm{e}}$ & $8.4^{\mathrm{e}}$ & $6.1^{\mathrm{d}}$ & $42.0^{\mathrm{a}}$ & $8.2^{\mathrm{e}}$ & $0.72^{\mathrm{c}}$ & $1.24^{\mathrm{c}}$ & $3.42^{\mathrm{d}}$ & 0.36 \\
\hline $\mathrm{Tl}$ & $50.3^{\mathrm{d}}$ & $38.8^{d}$ & $11.5^{\mathrm{c}}$ & $22.8^{c}$ & $20.3^{\mathrm{d}}$ & $2.50^{\mathrm{b}}$ & $3.24^{\mathrm{b}}$ & $6.77^{\mathrm{c}}$ & 0.37 \\
\hline $\mathrm{T} 2$ & $63.8^{c}$ & $47.5^{c}$ & $16.3^{b}$ & $25.5^{\mathrm{bc}}$ & $24.0^{c}$ & $2.63^{b}$ & $3.53^{b}$ & $7.25^{\mathrm{bc}}$ & 0.36 \\
\hline T3 & $97.0^{\mathrm{a}}$ & $71.0^{\mathrm{a}}$ & $26.0^{\mathrm{a}}$ & $26.8^{\mathrm{bc}}$ & $36.5^{\mathrm{a}}$ & $3.46^{\mathrm{a}}$ & $4.72^{\mathrm{a}}$ & $8.56^{\mathrm{a}}$ & 0.40 \\
\hline $\mathrm{T} 4$ & $88.4^{\mathrm{b}}$ & $65.2^{\mathrm{b}}$ & $23.3^{\mathrm{a}}$ & $26.3^{\mathrm{bc}}$ & $32.6^{\mathrm{b}}$ & $3.17^{\mathrm{a}}$ & $4.30^{\mathrm{a}}$ & $7.74^{\mathrm{b}}$ & 0.41 \\
\hline $\mathrm{T} 5$ & $91.2^{\mathrm{b}}$ & $64.7^{\mathrm{b}}$ & $26.6^{\mathrm{a}}$ & $29.1^{\mathrm{b}}$ & $32.8^{\mathrm{b}}$ & $3.06^{\mathrm{a}}$ & $4.32^{\mathrm{a}}$ & $7.73^{b}$ & 0.40 \\
\hline $\mathrm{P}$ & $* * *$ & $* * *$ & $* * *$ & $* *$ & $* * *$ & $* * *$ & $* * *$ & $* * *$ & ns \\
\hline
\end{tabular}

FW, fresh weight; DW, dry weight; HI, harvest index; T0, treatment 0 (restoration of 0 , irrigated only at transplanting time); T1, treatment 1 (restoration of 50); T2, treatment 2 (restoration of 75); T3, treatment 2 (restoration of 100); T4, treatment 2 (restoration of $100-75$ ); T5, treatment 2 (restoration of $100-50$ ). ${ }^{* *} \mathrm{P}<0.01$; ${ }^{* * *}<<0.001$. ns, not significant. ${ }^{\text {a-e }}$ Means followed by the same letters in the same column and within each year are not significantly $(\mathrm{P} \leq 0.01)$ different according to the SNK test. 


\section{Results}

\section{Rainfall, temperature and evapotranspiration}

As reported in Figure 1, the first tomato crop cycle, with 232 $\mathrm{mm}$, was more rainy than the second one $(117.6 \mathrm{~mm})$. In particular, the cropping cycle in 2003 was characterised by a lack of rainfall in June and July, except for a 24-mm rainfall on the $31^{\text {st }}$ of July. Even August was rather dry; only two rainfalls, 13 and $13.8 \mathrm{~mm}$ took place on the $24^{\text {th }}$ and the $25^{\text {th }}$ of August, respectively. The first 10 days of September were particularly rainy, with $41 \mathrm{~mm}$ of rainfall.

The monthly average daily temperature was higher in 2003 than in 2002. In 2002 the air temperature was higher during the first part of the crop cycle (June) when the maximum temperatures were almost always over $30^{\circ} \mathrm{C}$. Afterwards, in July, the daily minimum and maximum temperatures decreased, particularly in the second half of the month, and followed the same trend until the end of August (Figure 1). In 2003 the air temperature was particularly high in June, July and August, with a daily minimum temperature of approximately $19-20^{\circ} \mathrm{C}$, on average. Maximum temperatures were between 34 and $35^{\circ} \mathrm{C}$, on average, with peaks of $39-40^{\circ} \mathrm{C}$ in the last 10 days of July and the second 10 days of August, when even high night temperatures, which reduced thermal excursions, were recorded. Temperatures decreased markedly in September, with mean values for minimum and maximum daily temperatures of 13.8 and $25.9^{\circ} \mathrm{C}$, respectively.

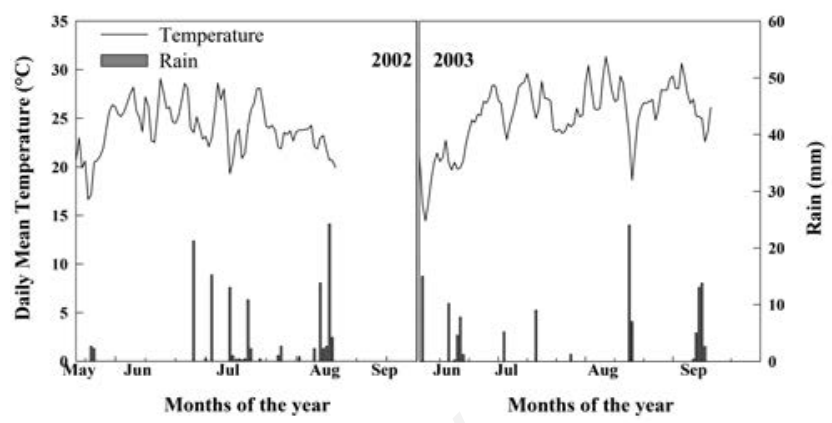

Figure 1. Daily mean temperature and rain for the experimental site during the years of the field trial.

Table 3. Average fruit weight, dry matter (total solids), soluble solids, $\mathrm{pH}$, titratable acidity and vitamin $\mathrm{C}$ content measured in the different irrigation treatments, for each year.

\begin{tabular}{|c|c|c|c|c|c|c|}
\hline Irrigation treatments & $\begin{array}{l}\text { Fruit weight } \\
\text { (g) }\end{array}$ & $\begin{array}{l}\text { TS (\%) } \\
\text { ( }{ }^{\circ} \text { Brix) }\end{array}$ & SS & $\begin{array}{l}\mathrm{pH} \\
(\%)\end{array}$ & $\begin{array}{l}\text { Titratable acidity } \\
\left.\text { (mg } 100 \mathrm{~g}^{-1}\right)\end{array}$ & Vitamin C \\
\hline \multicolumn{7}{|l|}{2002} \\
\hline T0 & $38.7^{\mathrm{c}}$ & $7.03^{\mathrm{a}}$ & $5.75^{\mathrm{a}}$ & $4.20^{\mathrm{b}}$ & 0.32 & 19.1 \\
\hline $\mathrm{T} 1$ & $48.6^{\mathrm{b}}$ & $5.97^{\mathrm{b}}$ & $5.47^{\mathrm{bc}}$ & $4.34^{\mathrm{a}}$ & 0.26 & 22.1 \\
\hline $\mathrm{T} 2$ & $59.1^{\mathrm{a}}$ & $5.62^{\mathrm{c}}$ & $5.13^{\mathrm{d}}$ & $4.29^{\mathrm{ab}}$ & 0.28 & 20.7 \\
\hline $\mathrm{T} 3$ & $47.2^{\mathrm{b}}$ & $5.70^{\mathrm{c}}$ & $5.23^{\mathrm{cd}}$ & $4.33^{\mathrm{a}}$ & 0.34 & 17.9 \\
\hline $\mathrm{T} 4$ & $61.2^{\mathrm{a}}$ & $5.57^{\mathrm{c}}$ & $5.37^{\mathrm{bd}}$ & $4.28^{\mathrm{ab}}$ & 0.40 & 18.6 \\
\hline $\mathrm{T} 5$ & $59.8^{\mathrm{a}}$ & $5.55^{\mathrm{c}}$ & $5.63^{\mathrm{ab}}$ & $4.22^{\mathrm{ab}}$ & 0.34 & 22.0 \\
\hline $\mathrm{P}$ & $* * *$ & $* * *$ & $* * *$ & $*$ & ns & ns \\
\hline \multicolumn{7}{|l|}{2003} \\
\hline T0 & $35.0^{\mathrm{b}}$ & $8.50^{\mathrm{a}}$ & $7.03^{\mathrm{a}}$ & $4.41^{\mathrm{a}}$ & $0.54^{\mathrm{a}}$ & $30.6^{\mathrm{a}}$ \\
\hline $\mathrm{T} 1$ & $65.3^{\mathrm{a}}$ & $6.43^{b}$ & $4.53^{\mathrm{b}}$ & $4.42^{\mathrm{a}}$ & $0.31^{\mathrm{d}}$ & $24.2^{b}$ \\
\hline $\mathrm{T} 2$ & $67.3^{\mathrm{a}}$ & $5.53^{\mathrm{c}}$ & $4.47^{\mathrm{b}}$ & $4.41^{\mathrm{a}}$ & $0.42^{b}$ & $24.5^{b}$ \\
\hline $\mathrm{T} 3$ & $66.2^{\mathrm{a}}$ & $4.87^{\mathrm{d}}$ & $3.83^{\mathrm{d}}$ & $4.41^{\mathrm{a}}$ & $0.31^{\mathrm{d}}$ & $25.3^{\mathrm{b}}$ \\
\hline T4 & $68.1^{\mathrm{a}}$ & $4.87^{\mathrm{d}}$ & $3.97^{\mathrm{cd}}$ & $4.40^{\mathrm{a}}$ & $0.27^{d}$ & $25.1^{\mathrm{b}}$ \\
\hline $\mathrm{T} 5$ & $67.2^{\mathrm{a}}$ & $4.73^{\mathrm{d}}$ & $4.03^{c}$ & $4.50^{\mathrm{b}}$ & $0.36^{c}$ & $21.8^{c}$ \\
\hline P & $* * *$ & $* * *$ & $* * *$ & $* * *$ & $* * *$ & $* * *$ \\
\hline
\end{tabular}

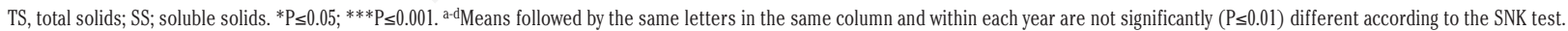

Table 4. Factor loadings, eigenvalues and percentages of total variance for the two principal components derived from tomato quality parameters measured in 2002 and 2003.

\begin{tabular}{|c|c|c|c|c|}
\hline & & Pri & & \\
\hline & & & & \\
\hline Measurement & $\mathrm{PCl}$ & PC2 & $\mathrm{PCl}$ & PC2 \\
\hline Mean fruit FW & -0.76 & -0.16 & -0.97 & -0.13 \\
\hline $\mathrm{TS}$ & 0.94 & 0.06 & 0.95 & 0.03 \\
\hline SS & 0.85 & 0.03 & 0.98 & 0.13 \\
\hline $\mathrm{pH}$ & -0.66 & 0.34 & -0.35 & 0.92 \\
\hline Titratable acidity & -0.01 & -0.96 & 0.86 & 0.35 \\
\hline Vitamin C & -0.04 & 0.76 & 0.93 & -0.29 \\
\hline Eigenvalue & 2.65 & 1.66 & 4.58 & 1.10 \\
\hline Total variance (\%) & 44.24 & 27.62 & 76.4 & 18.41 \\
\hline
\end{tabular}

FW, fresh weight; TS, total solids; SS, soluble solids; PC1, principal component 1; PC2, principal component 2. Factor loadings $>0.7$ are considered statistically significant and are reported in italics. 
In 2002, the cumulative reference ET (ETo) was $629 \mathrm{~mm}$ and the cumulative ETc was $470 \mathrm{~mm}$. In 2003 ETo was high during most of the crop cycle, except for September. The highest daily values, equal to or greater than $10 \mathrm{~mm}$, were recorded for 4 days in June, for 5 days in July and for only one day in August. Cumulative ETo and ETc were 699 and $625 \mathrm{~mm}$, respectively.

\section{Tomato yield}

The effects of different irrigation regimes on the tomato yield in the two experimental years are summarised in Table 2. The total yield, on average, was higher in 2002 than in 2003 (98 and $67.5 \mathrm{t}$ $\mathrm{ha}^{-1}$, respectively). In 2002, the highest total yield, approx. $124 \mathrm{t}$ $\mathrm{ha}^{-1}$, was recorded under full irrigation (T3) then $75 \%$ ETc (T2) resulted in yields (110 t ha $\mathrm{t}^{-1}$ on average) not different from treatments with an irrigation cutback (T4 and T5). The lowest total yield $\left(42.6 \mathrm{t} \mathrm{ha}^{-1}\right)$ was recorded in the dry control (T0). The highest total yield in 2003, as well, approximately $97 \mathrm{t} \mathrm{ha}^{-1}$, was obtained with full irrigation (T3), but differently than what occurred in 2002, treatments with irrigation cutback produced more than T2 treatment (75\% ETc rest). The marketable yield in 2002, did not differ among T2, T3, T4, and T5 treatments $\left(67.9 \mathrm{t} \mathrm{ha}^{-1}\right.$ on average); a lower yield in the T1 treatment $\left(56.0 \mathrm{t} \mathrm{ha}^{-1}\right)$. The lowest marketable yield was obtained in the dry control $\left(21.4 \mathrm{t} \mathrm{ha}^{-1}\right)$. In 2003, as well, the irrigation treatments clearly differed for productivity, with the highest marketable yield levels in the T3 treatment $\left(71 \mathrm{t} \mathrm{ha}^{-1}\right)$. The lowest yields corresponded to treatments T2, T1 and T0. For both years, the highest amount of discarded tomatoes was recorded for T3, T4 and T5 treatments, while the lowest in T0 treatment. However, in percentage terms compared to total yield (i.e. yield loss), the latter parameter was higher in the dry control than the different irrigation treatments. Regarding the marketable dry yield, very similar values were observed for the treatment with full irrigation and for treatments with irrigation cutback, while the values of number of fruits per plant showed, in both years, the same trend of marketable yield (Table 2). No significant differences were observed among harvest index (HI) values in both years.

\section{Water use efficiency}

Values of water-use efficiency (WUE) calculated for the various irrigation treatments in both years are summarised in Figure 2 as expected, in both years the WUE gradually increased from the fully irrigated to the dry treatment, proving that tomato used the water more efficiently under stress conditions. In fact, this parameter ranged between $4.94 \mathrm{~kg} \mathrm{~m}^{-3}$ (T0) and $2.04 \mathrm{~kg} \mathrm{~m}^{-3}$ (average of $\mathrm{T} 3$ and T4), in the first year, and between $3.22 \mathrm{~kg} \mathrm{~m}^{-3}$ (T0) and $1.58 \mathrm{~kg} \mathrm{~m}^{-3}$ (average of T2, T3, T4 and T5), in the second one (Figure 2).

\section{Fruit quality}

Irrigation treatments significantly affected tomato fruit quality in both years but in different ways, according to the climatic trends (Table 3 and Figure 1).

In 2002, the mean fruit weight was significantly higher in treatments with irrigation cutback (60.5 g on average) and in T2 one (59.1). The fruit dry matter (TS) was higher in the dry control $(7.0 \%)$ and lower in T2, T3, T4 and T5 treatments $(5.6 \%$ on average). The soluble solids (SS) content was higher in T0 and T5 (5.69 ${ }^{\circ}$ Brix on average) and lower in T2 and T3 treatments $\left(5.18{ }^{\circ}\right.$ Brix on average) (Table 3 ). $\mathrm{pH}$ was higher in $\mathrm{T} 1$ and $\mathrm{T} 3$ treatments (4.33 on average) and lower in T0 (4.2). No significant effects were observed on titratable acidity and on the vitamin $\mathrm{C}$ content.
In 2003, the average fruit weight was greatly lower in T0 $(35.0 \mathrm{~g})$ than the other treatments that have not differentiated among themselves (66.8 $\mathrm{g}$ on average). Similarly to the first year, the TS was higher in the dry control $(8.5 \%)$ and lower in T3, T4 and $\mathrm{T} 5$ treatments $(4.82 \%$ on average). The highest value for the SS was recorded in the dry control $\left(7.03{ }^{\circ}\right.$ Brix $)$ while the lowest in T3 treatment $\left(3.83^{\circ}\right.$ Brix) (Table 3$)$. The highest $\mathrm{pH}$ was observed in T5 (4.50), while other treatments had a lower value (4.41 on average) and were not differentiated among themselves. Titratable acidity was higher in T0 $(0.54 \%)$ and lower in T1, T3 and T4 $(0.30 \%$ on average). The vitamin $\mathrm{C}$ content was also affected by irrigation; the higher value was observed in the dry control $(30.6$ $\left.\mathrm{mg} 100 \mathrm{~g}^{-1}\right)$, the lowest one in the T5 treatment $\left(21.8 \mathrm{mg} 100 \mathrm{~g}^{-1}\right)$.

\section{Principal component analysis results}

In Figure 3 and Table 4, the results of the PCA on tomato quality parameters are reported for 2002 and 2003. For the first year, $71.86 \%$ of the variance could be explained by the two main components having an eigenvalue greater than 1, according to the Kaiser criterion (Kaiser, 1960). The loading plot of PC1 (44.24\% of total variance) $v s$ PC2 (27.62\%, Figure 3A) showed a clear separation among different irrigation treatments for the investigated parameters. Dry matter and soluble solids had positive values for PC1, whereas the mean fruit weight had a negative value for PC1.
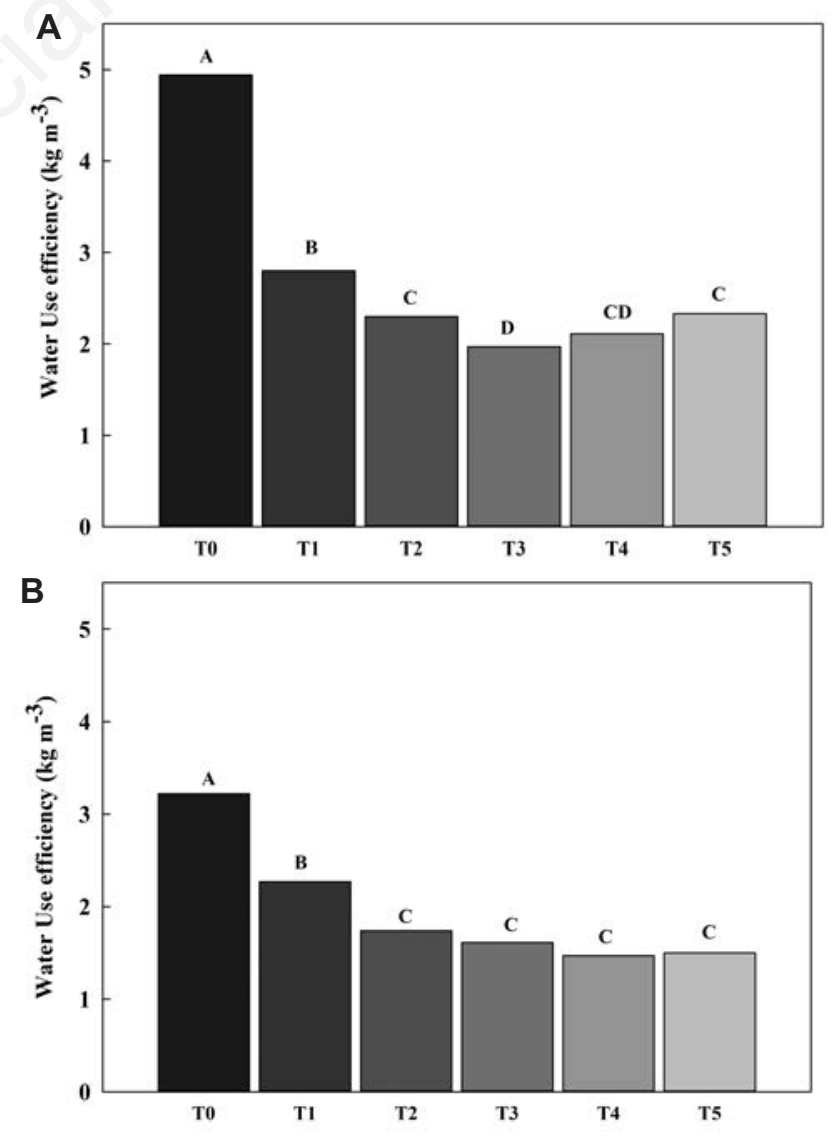

Figure 2. Water use efficiency calculated for the different treatments during 2002 (A) and 2003 (B). Bars with the same letters are not significantly $(P<0.01)$ different according to the StudentNewman-Keuls test. 
Titratable acidity had a negative value for $\mathrm{PC} 2$, and the vitamin $\mathrm{C}$ content had a good positive correlation with PC2. For the second year, $94.81 \%$ of the variance can be explained by two main components having an eigenvalue greater than 1 (Table 4). The loadings plot of PC1 (76.40\% of total variability) vs PC2 (18.41\%, Table 4 and Figure 3B) showed a clear separation among treatments for the investigated parameters, for the second year as well. Additionally, in 2003, dry matter and soluble solids had positive values for $\mathrm{PC} 1$, whereas the mean fruit weight had a negative value for PC1. Moreover, for 2003, titratable acidity and vitamin C had a positive value for $\mathrm{PC} 1$ and $\mathrm{pH}$ had a positive value for $\mathrm{PC} 2$. The PCA graph (Figure 3) showed that the mean fruit weight, dry matter, soluble solids, titratable acidity and vitamin $\mathrm{C}$ in tomatoes contribute to most of differences among the irrigation treatments and $\mathrm{pH}$ only for the second year (Table 4). Irrigation cutback (T5 treatment) is located on the positive axis of PC2 during 2003, showing a meaningful characterisation of tomato fruit quality based on this irrigation treatment.

\section{Discussion}

Under the specific conditions of this experiment, we observed a strong effect of irrigation regime on the yield and quality of processing tomato, which is in agreement with the findings from other authors (Cahn et al., 2001; Dumas et al., 2003; Marouelli and Silva, 2007; Ozbahce and Tari, 2010; Pernice et al., 2010; Patanè et al., 2011). Our results were influenced by the weather conditions, quite different in the two experimental years In particular, during the first growing season (2002) occurred cool and rainy weather conditions, whereas in 2003 , temperatures were very high and rainfall was absent until the beginning of the fruit development. These differences may have accounted for the results obtained in the two years of the experiment, in terms of WUE, yield and during the first growing season (2002) the crop quality.

Both total and marketable yields were greatly reduced with a $50 \%$ cut of ETc restoration respect to fully irrigation control $(100 \%$ $\mathrm{ETc})$. Many authors highlighted yield reductions in processing tomato due to deficit irrigation (Marouelli and Silva, 2007; Patanè and Cosentino, 2010; Patanè et al., 2011).

In particular, an irrigation technique was developed on the tomato that consists of interrupting watering (irrigation cut-off)
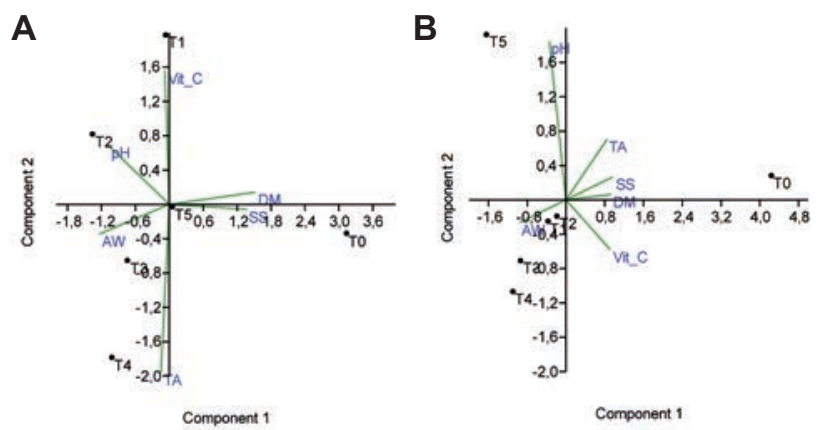

Figure 3. Biplot of two principal components (PC1 and PC2) for quality parameters measured in tomato fruits in 2002 (A) and 2003 (B). during the ripening period, with the final goal of saving water and improving dry matter accumulation, although this technique also causes a reduction in the marketable yield (Cahn et al., 2003; Lowengart-Aycicegi et al., 1999). Our results are in agreement with those obtained by Cahn et al. (2001) because the irrigation interrupted at the onset of fruit ripening does not affect yield, especially in terms of marketable dry matter; whilst maximises WUE, resulting in a water saving. In 2002, $918 \mathrm{~m}^{3} \mathrm{ha}^{-1}$ was saved and WUE was increased from 1.97 to $2.33 \mathrm{~kg} \mathrm{~m}^{-3}$, fully irrigation control (T3) to 50\% ETc cutback (T5). Fruit quality of the processing tomato depends greatly on irrigation. Usually, the effect of deficit irrigation on fruit quality is the opposite of that on fruit yield and weight (Patanè et al., 2011; Cantore et al., 2016). In our experiment, mean fruit weight was always lower in deficit irrigation treatments compared to the other irrigation treatments. Furthermore, TS and SS were the highest in plots were a 50\% ETc restoration was applied for the whole growing season (T1) reaching their minimum values in fully irrigated treatment (T3). Other authors have also shown that fruit weight, diameter and acidity increased with irrigation (Colla et al., 1999; Patanè and Cosentino, 2010; Garnett et al., 2013; Cantore et al., 2016) but SS and TS decreased (Colla et al., 1999). The effect of irrigation cutback late in growing season gave distinct results (May and Gonzales, 1999; Johnstone et al., 2005; Marouelli et al., 2004).

The SS content was affected by the phenological stage at which irrigation was stopped, since they did not change when irrigation was applied during the vegetative and fruit development, but strongly increased as water stress was applied during fruit ripening (Marouelli et al., 2004; Johnstone et al., 2005). Our results show that the high SS content in the tomatoes under the irrigation cutback treatments are in agreement with these authors (Marouelli et al., 2004; Johnstone et al., 2005). The $\mathrm{pH}$ was below 4.3 , which is considered a good value according to the reference scale of analytical parameters for processing tomato pulp (Siviero, 1998). ANOVA highlighted significant differences among irrigation treatments on tomato yield and quality. However, to better investigate the complex interactions between the agronomic traits and fruit quality, we processed data also by the PCA analysis. Studies on heat-treated strawberry fruits (Musto and Satriano, 2010) showed that PCA can give a meaningful characterisation of fruit samples based on heat treatment time and can help identify which variables contribute most to their differences. In the current study, the multivariate approach (PCA analysis) gave a preliminary reading of the parameters that may contribute more to the separation among irrigation treatments. Our approach is in agreement with that of other authors (Suárez et al., 2011). Projections of the tomato quality parameters on the subspace of the PCA are called loadings and coincide with the correlation coefficients between principal components and parameters. From the analysis of the loading of the two retained principal components (Table 4) and from the PCA biplot (Figure 3), we extracted two latent variables (principal components) that explain most of the variance in the original data set. Through the analysis of PC1 and PC2, we isolated quality parameters that contribute most to the differences among the irrigation treatments. In both years, these parameters were the mean fruit weight, dry matter (TS), soluble solids (SS), titratable acidity and vitamin $C$. The positioning of the irrigation cutback treatment (T5 treatment) on the positive axis of the PCA biplot for both years showed its good correlation with tomato quality and clearly showed the positive impact of this irrigation regime on fruit quality. 


\section{Conclusions}

The two-year research project confirms the following hypothesis: a limited soil water availability leads to decreased tomato yield but also leads to high fruit quality in tomato. Through the application of irrigation cutback late in growing season (at the onset of fruit ripening), fruit quality may be improved in tomato and, at the same time, irrigation water may be saved and water-use efficiency is improved. Therefore, this irrigation strategy may be a valid option for cultivated semi-arid Mediterranean areas. Multivariate analysis (PCA) confirmed that the irrigation cutback technique was well correlated with tomato quality. We isolated tomato quality parameters that contributed the most to the differences among deficit irrigation and full irrigation treatments, and these were the mean fruit weight, dry matter, soluble solids, titratable acidity and vitamin $\mathrm{C}$ content.

\section{References}

Buttaro D, Santamaria P, Signore A, Cantore V, Boari F, Montesano FF, Parente A, 2015. Irrigation management of greenhouse tomato and cucumber using tensiometer: effects on yield, quality and water use. Agric. Agricultural Sci. Procedia 4:440-4.

Cahn MD, Herrero EV, Hanson BR, Snyder RL, Hartz TK, Miyao EM, 2003. Effects of irrigation cutoff on processing tomato fruit quality. Acta Hortic. 613:75-80.

Cahn MD, Herrero EV, Snyder RL, Hanson BR, 2001. Water management strategies for improving fruit quality of drip-irrigated processing tomatoes. Acta Hortic. 542:111-6.

Campbell GS, Gee GW, 1986. Water potential: miscellaneous methods. In: Methods of soil analysis. American Society of Agronomy-Soil Science Society of America, Madison, WI, USA. pp. 619-33.

Candido V, Campanelli G, D'Addabbo T, Castronuovo D, Perniola M, Camele I, 2015. Growth and yield promoting effect of artificial mycorrhization on field tomato at different irrigation regimes. Sci. Hortic. 187:35-43.

Candido V, Miccolis V, Perniola M, 2000. Effects of irrigation regime on yield and quality of processing tomato (Lycopersicon esculentum Mill.) cultivars. Acta Hortic. 537:779-88.

Cantore V, Iovino F, Pontecorvo G, 1987. Aspetti climatici e zone fitoclimatiche della Basilicata. Grafiche Badiali s.n.c. ed., Arezzo Italy.

Cantore V, Lechkar O, Karabulut E, Sellami MH, Albrizio R, Boari F, Stellacci AM, Todorovic M, 2016. Combined effect of deficit irrigation and strobilurin application on yield, fruit quality and water use efficiency of "cherry" tomato (Solanum lycopersicum L.). Agr. Water Manage. 167:53-61.

Colella T, Candido V, Campanelli G, Camele I, Battaglia D, 2014. Effect of irrigation regimes and artificial mycorrhization on insect pest infestations and yield in tomato crop. Phytoparasitica 42:235-46.

Colla G, Casa R, Locascio B, Saccardo F, Temperini O, Leoni C, 1999. Responses of processing tomato to water regime and fertilization in Central Italy. Acta Hortic. 487:531-5.

Dumas Y, Dadomo M, Di Lucca G, Grolier P, 2003. Effects of environmental factors and agricultural techniques on antioxidant content of tomatoes. J. Sci. Food. Agric. 83:369-82.
Fereres E, Soriano MA, 2007. Deficit irrigation for reducing agricultural water use. J. Exp. Bot. 58:147-59.

Garnett T, Appleby MC, Balmford A, Bateman IJ, Benton TG, Bloomer P, Burlingame B, Dawkins M, Dolan L, Fraser D, Herrero M, Hoffmann I, Smith P, Thornton PK, Toulmin C, Vermeulen SJ, Godfray HC, 2013. Sustainable intensification in agriculture: premises and policies. Science 341:33-4.

Geerts S, Raes D, 2009. Deficit irrigation as an on-farm strategy to maximize crop water productivity in dry areas. Agr. Water Manage 96:1275-84.

Giuliani MM, Gatta G, Nardella E, Tarantino E, 2016. Water saving strategies assessment on processing tomato cultivated in Mediterranean region. Ital. J. Agron. 11:69-76.

Jackson JE, 1991. A users guide to principal components. Wiley \& Sons Ltd., Chichester, UK.

Johnstone PR, Hartz TK, LeStrange M, Nunez JJ, Miyao EM, 2005. Managing fruit soluble solids with late-season deficit irrigation in drip-irrigated processing tomato production. Hortic. Sci. 40:1857-61.

Kaiser HF, 1960. The application of electronic computers to factor analysis. Educ. Psychol. Meas. 20:141-51.

Kirda C, Cetin M, Dasgan Y, Topcu S, Kaman H, Ekici B, Derici M.R, Ozguven AI, 2004. Yield response of greenhouse grown tomato to partial root drying and conventional deficit irrigation. Agr. Water Manage. 69:191-201.

Lovelli S, Perniola M, Di Tommaso T, Ventrella D, Moriondo M, Amato M, 2010. Effects of rising atmospheric $\mathrm{CO}_{2}$ on crop evapotranspiration in a Mediterranean area. Agr. Water Manage. 97:1287-92.

Lovelli S, Perniola M, Scalcione E, Troccoli A, Ziska LH, 2012. Future Climate change in the Mediterranea area: implications for water use and weed management. Ital. J. Agron. 7:44-9.

Lowengart-Aycicegi A, Manor R, Krieger R, Gera G, 1999. Effects of irrigation scheduling on drip-irrigated processing tomatoes. Acta Hortic. 487:513-8.

Marouelli WA, Silva WLC, 2007. Water tension thresholds for processing tomatoes under drip irrigation in Central Brazil. Irrigation Sci. 25:41-418.

Marouelli WA, Silva WLC, Moretti CL, 2004. Production, quality and water use efficiency of processing tomato as affected by the final irrigation timing. Hort. Bras. 22:225-30.

May DM, Gonzales J, 1999. Major California processing tomato cultivars respond differently in yield and fruit quality to various levels of moisture stress. Acta Hortic. 487:525-9.

Musto M, Satriano ML, 2010. Fruit responses to postharvest heat treatment time: characterisation of heat-treated strawberry (Fragaria x ananassa) cv. 'Candonga' fruits. Agron. Res. 8:81526.

Obreza, TA, Pitts, DJ, McGovern RJ, Spreen TH, 1996. Deficit irrigation of microirrigated tomato affects yield, fruit quality, and disease severity. J. Prod. Agric. 9:270-5.

Ozbahce A, Tari AF, 2010. Effects of different emitter space and water stress on yield and quality of processing tomato under semi-arid climate conditions. Agr. Water Manage. 97:1405-10.

Patanè C, Cosentino SL, 2010. Effects of soil water deficit on yield and quality of processing tomato under a Mediterranean climate. Agr. Water Manage. 97:131-8.

Patanè C, Tringali S, Sortino O, 2011. Effects of deficit irrigation on biomass,yield, water productivity and fruit quality of processing tomato under semi-arid Mediterranean climate conditions. Sci. Hortic. 129:562-71.

Pernice R, Parisi M, Giordano I, Pentangelo A, Graziani G, Gallo M, Fogliano V, Ritieni A, 2010. Antioxidants profile of small 
tomato fruits: effects of irrigation and industrial process. Sci. Hortic. 126:156-63.

Pulupol LU, Behboudian MH, Fisher KJ, 1996. Growth, yield, and postharvest attributes of glasshouse tomatoes produced under deficit irrigation. Hortic. Sci. 31:926-9.

Sanders DC, Howell TA, Hile MMS, Hodges L, Meek D, Phene CJ, 1989. Yield and quality of processing tomatoes in response to irrigation rate and schedule. J. Am. Soc. Hortic. Sci. 114:904-8.

Siviero P, 1998. Aspetti qualitativi del pomodoro da industria. Inf. Agrario 34:63-7.

Stellacci A, Castrignanò A, Diacono M, Troccoli A, Ciccarese A, Armenise E, Gallo A, De Vita P, Lonigro A, Mastro MA, Rubino P, 2012. Combined approach based on principal com- ponent analysis and canonical discriminant analysis for investigating hyperspectral plant response. Ital. J. Agron. 7:247-53.

Suárez M, Méndez E, Galdón B, Rodríguez E, Romero C, 2011. Influence of agronomic variables on quality of tomato fruits. Agr. Sci. 2:424-31.

Tarantino E, Onofri M, 1991. Determinazione dei coefficienti colturali mediante lisimetri. Bonifica 8:119-36.

Wold S, Esbensen K, Geladi P, 1987. Principal component analysis. Chemom Intell. Lab. Syst. 2:37-52.

Zheng J, Huang G, Jia D, Wang J, Mota M, Pereira LS, Huang Q, $\mathrm{Xu}$ Xuab, Haijun Li H, 2013. Responses of drip irrigated tomato (Solanum lycopersicum L.) yield, quality and water productivity to various soil matric potential thresholds in an arid region of Northwest China. Agr. Water Manage. 129:181-93. 